\title{
Life, survival and "care" in times of occupation
}

\author{
FRENY MANECKSHA
}

\section{Saiba Varma, The Occupied Clinic: Militarism and Care in Kashmir. Duke University Press, Durham and London; 2020, 304 pages, \$27.95 (Paperback), \$19.20 (Kindle), ISBN: 978-1-4780-1098-2}

"During fieldwork, I was often given friendly warnings, like 'you never know who anyone is in Kashmir,' a statement meant to warn me not to trust too easily, given the long-standing history of informers, spies and collaborators in Kashmir. Several times after I interviewed someone, I learned of their 'other' identity as a former militant, collaborator, or someone with high-up state connections. This knowledge, a virtual map overlaid on everyday sociality, always came after the fact, and it unnerved me. How would I ever grasp these subterranean histories? I also worried about the virtual map circulating about me: Who was I spying for? Did people trust me?"

Saiba Varma, The Occupied Clinic: Militarism and Care in Kashmir

Was there a sense of foreboding in this paragraph written by medical anthropologist Saiba Varma in her book, The Occupied Clinic: Militarism and Care in Kashmir? The book, described as "beautifully crafted ethnography", deals with entanglements between medicine, mental health and militarism, and received the Edie Turner First Book Prize presented by the Society for Humanistic Anthropology section of the American Anthropological Association.

But, on September 14, the issue of ethical concerns and charge of "spy" rang out in social media. An anonymous handle on Twitter said Varma's father was an "integral part of India's intelligence and espionage establishment" and "was an agent in Research and Analysis Wing who held 'sensitive assignments in Kashmir."(1)

Author: Freny Manecksha (frenym@gmail.com), Independent Journalist and Author, Mumbai, INDIA.

To cite: Manecksha F. Life, survival and "care" in times of occupation. Indian $J$ Med Ethics. Published online on December 18, 2021. DOI: 10.20529/IJME. 2021.097

Manuscript Editor; Sanjay A Pai

C Indian Journal of Medical Ethics 2021
The tweets charged Varma with not having "disclosed her compromised family background in writings or interviews". They raised questions about "positionality, methods, consent \& especially honesty \& transparency with vulnerable informants - mostly PTSD patients who have suffered at the hands of the Indian military and intelligence establishment." (1)

In the chaotic spaces of social media, Varma was criticised, not just by liberal Indian academics and Kashmir scholars for this non-disclosure, but also by right wing nationalists for having written a book that dealt with the occupation. Former RAW chiefs A S Dulat and Vikram Sood jumped into the fray (2), inexplicably defending a book which speaks of "unparalleled militarization and securitization, and unfulfilled demands for independence...". (p 8)

The controversy was discussed in academic spaces: Kashmir Scholars Consultative and Action Network (KSCAN), with whom Varma was associated, issued a statement saying that while it did not hold that a daughter should be punished for the father's sins, it was a clear breach of ethical responsibility for the researcher to not disclose, or to misrepresent, intimate family links with the colonial state. It sought collective deliberation on how scholars positioned across "vast power differentials of caste, class and nationality can conduct research among besieged populations in the militarized colonial state in an ethically responsible manner."(3)

A group of 53 scholars in India and abroad also raised questions of informed consent. They said Varma, as an anthropologist trained in the United States, is bound by the American Anthropological Association's Code of Ethics which clearly states that anthropologists should first strive to "do no harm" and be "open and honest" regarding their work (3).

In her statement released some weeks later in public forums, Varma said her father worked in Kashmir, without any family present, in the early 1990s, when she was 10 years old. Since then, he has never held any positions related to Kashmir. She added, "He has never shared any details of his work with me. During my fieldwork, I did not use his position to condition any of my relationships. My work has never been funded or facilitated by the Indian government or any of its agencies. My father did not read a word of my manuscript until after my book was published, because I did not want his perspectives to colour mine in any way."(3). (Her father died on December 10 this year, after this review was written). 
Varma said she did not breach any ethical standards in her field work. Her interlocutors, who included mental health practitioners, humanitarian aid workers, NGO workers, patients, hospital administrators, journalists, professors, writers, artists, and activists, had reassured her that no harm had been caused and confirmed she had been working independently.

At the crux of this controversy is what researchers term as "positionality." That is the social and political context that creates your identity in terms of race, class, gender, sexuality and ability status. It raises the crucial question of whether there is an imbalance of power and privilege that can be harmful, and whether it has led to transgressions.

There can be no doubt that as far as ability and class are concerned, Varma, and many others who hold positions as professors and are associated with the most elite universities in the United States of America, enjoy huge privilege. Added to this is identity that accrues, simply by virtue of being Indian, when in Kashmir. This applies not just to journalists, writers, scholars doing field work, but even to ordinary visitors.

My own identity and privilege became clear to me way back in 2011 when I visited the Valley. Police stopped the share taxi in which I was enroute to the Islamic University in Awantipora. The Kashmiri students, escorting me to a film festival, were asked to produce identity cards and questioned about where they were going. I, the outsider and Indian, was not!

Her privilege is freely acknowledged by Varma in her book, where in the first few pages, she refers to the soldier in a bunker who has a clear view of everyone who comes and goes. She adds, "the back of my neck bristles, even though my identity as a non-Kashmiri protects me from harm". (p 9)

In contrast are the very real fears of Kashmiri researchers. There has been increasing surveillance of Kashmiri academics, journalists and historians. Some academicians, who had visited home recently, found they had been placed on a "no fly list" in India. They were interrogated by the cyber cell and asked to sign a bond before they were allowed to return to their posts in universities abroad.

I asked Varma, in an email, to elaborate on the paragraph quoted at the beginning of this review. She replied that the passage was one among many "in which I reflect on what it means for someone of Indian origin to do research in Kashmir. We must understand where this mistrust comes from and what its social function is." (4)

Rather than see her own situation as exceptional, her discussions with people in Kashmir, and her experiences of fieldwork, demonstrated that contradictions were part of the very conditions of militarisation itself. "For example, aside from my family history, simply being an Indian/outsider was enough for some to cast me as suspect and as a potential spy. It took me many years to establish relationships of trust and respect with Kashmiri colleagues and friends. Their respect and trust built, the more scholarship I produced because people could see my intentions more clearly. There is, in other words, a system of accountability that people in Kashmir adhere to and it is essential that Indian ethnographers in particular recognize that their work will be carefully read and scrutinized." (4)

Her reply suggests how privilege, besides being acknowledged, can also be a measure of how one chooses to exercise it. It opens up another crucial question pertaining to norms set by those in western countries. Can strict protocols, drawn up by the American anthropologists in the US, apply to "milieus of mistrust from which all knowledge operates" in the very complex and layered scenario of Kashmir? What about situations when a degree of circumspection is necessary? Aside from protocols, can one build respect and trust through one's works and intentions?

Whilst there can be no hard and fast answers to this thorny issue, Varma in her public statement said that "after more than 13 years of engagement with people in Kashmir I have learned that disclosure, much like consent itself, is not a onetime event, it happens contextually, relationally and processually."(3)

Interestingly, another paper on medicine and care that I came across, deals with similar issues and concerns. Anna Ruddock in her paper "Special Treatment: Student Doctors at The All India Institute of Medical Sciences" notes, "Although community based studies of illness experience and health seeking are well established in India, hospital ethnography remains a nascent subfield with its own methodological and ethical dilemmas."(5)

Ruddock, who was asked, at one point, if her work entailed spying, said she used verbal consent after explaining her role and nature of study whilst conducting short interviews because crowded conditions and minimal literacy of many patients made written consent impractical (5). In extremely crowded outpatient clinics she accepted the consent of the doctor holding the clinic to observe the interactions. It is similar to the practices Varma adopted.

Ruddock adds that the unstructured conversations she had were integral to her broader ethnographic material. For me, one of the merits of Varma's book is such unstructured learning and understanding, that she writes about. This is brought by her wide interaction with a spectrum of Kashmiri society and her lived experiences of Kashmir's curfews, hartals or shutdowns, of dodging the concertina wire barriers and coping with the communication shutdown. Many of these experiences through the periods of turmoil as in 2009 and 2010, the aftermath of the 2014 floods, the 2016 uprising, and the 2019 siege when Article 370 was abrogated, are interwoven into the book.

I had first met Varma briefly in Srinagar in 2010 after a summer of huge unrest. This was the period marked by civil 
disobedience, of protests by unarmed youths who came out on the streets in defiance, that were often followed by stonepelting. At least 110 people, mainly youths, died, and 537 civilians were injured that summer (6).

It was a time, Varma writes, when curfews and strikes disrupted flows of medicines, equipment, personnel, and professional opportunities. Hospitals, medical professionals, and ambulances were attacked and the culture of impunity, unleashed by unfettered emergency powers, had spread to medicine. Clinicians struggled, day after day, to shore up the clinic's therapeutic boundaries against violence.

Her writings subsequently dealt with Kashmir's public health crisis, especially with regard to mental health. Surveys showed that more than 60 per cent of Kashmiris were suffering from high levels of anxiety, nervousness, tension, extensive worrying and trauma that persist through their lifetimes ( $p 3$ ). The huge numbers of people with post-traumatic stress disorder or what came to be known as the "epidemic of trauma" was, Varma observes, actually "a sign of enormous psychological and emotional suffering" (p 8). Suffering that was a direct product of colonial, social, economic and political violence.

Her project, she says, was primarily about medical and psychiatric expertise and was conceptualised together with colleagues in Kashmiri hospitals who sought an anthropological account of the mental health crisis. "Rather than focus on victims of state violence, I documented the fallouts of humanitarian and psychiatric care as part of the broader logic of militarism. In so doing, my effort was to hold the state-and all its agents-accountable for its psychic violence, which remains invisible or difficult to capture."

Kashmiris, she explains in her book, do not see the distress as connected to just one specific event or to an individual body but instead located trauma both externally and internally through the use of terms like halat (situation) and mahaul (atmosphere).

Ironically, the same state and security forces that were the primary cause of trauma were also the ones who took up care interventions. Like other militaries, the Indian security forces used medical and other psychological technologies. Examples of such militarised care include substance abuse clinics run by the police, counselling and rehabilitation programmes for stone throwers, free medical and mental health camps and post-disaster relief.

Humanitarianism is also used to fulfil national goals, she explains. Subjects torn apart by state violence find themselves turning to those same institutions for redress.

Varma differentiates between this form of militaristic care and the humanitarian interventions by local and international NGOs and public health interventions which try to be neutral and apolitical. Whilst the intent of the police in employing professionals to conduct workshops and camps on mental health was to target young minds to understand "why youth are resorting to violent means of protest (ie stone pelting)", the approach of the NGOs was to encourage Kashmiris to imagine themselves as patients and victims rather than political subjects.

With these premises, Varma's book is constructed to attend to critical junctures - moments, practices and techniques when medicine and militarism merge.

Written as an ethnographic work, it is for the anthropologists and psychiatrists to critique the work and arguments. However, despite anthropological terminology, the style is fairly reader-friendly and there is much to reflect upon in this original portrayal of life, survival and care in conditions of occupation.

One narrative is about Shakeela, a Gujar woman, who still has nightmares about the military sieges, known as crackdowns or cordon and search operations*. She explains her condition as kamzori (weakness) brought about by too much worrying or pareshani. Even when crackdowns stopped, the kamzori persisted. Kamzori, concludes Varma, was thus the siege that became memorialised in bodies.

Varma uses this term, kamzori, to tie in to collective experiences of physical and structural violence that Kashmiris had suffered. Another narrative of kamzori is that of Inayat, diagnosed with schizophrenia, seeking treatment for substance abuse at the police-run drug de-addiction centre. He complained that the psychotropic medications he was given had turned into a land mine inside his body.

In his conversations with Varma, uncomfortable truths about entanglements of military and humanitarian apparatuses emerged. His father, who was in the police, was physically abusive and an alcoholic who abandoned the family. His brother Yousuf, who 'disappeared', had been approached to become a mukhbir or informer. Inayat himself began doing counter insurgency work with the police although he remained vague about what exactly he did. He was bitter that despite working for the police for five years in college, he did not get adequately paid, and was resentful he could not join the Task Force where killing of suspected militants is incentivised and rewarded. Human rights activists say this has created a perverse system in which Kashmiri civilians are routinely 'disappeared', killed and passed off as Pakistani terrorists.

A detailed analysis on unpacking the phrase used by Inayat of how medicine had turned into a pill, a land mine inside a body, follows. But even without such explanations, one can glean how Inayat's life history reveals the emotional and psychic dissonance that occurs when people's lives are torn apart by the schisms created by militarism, and when militarised care is the only available mode of redress.

Sohaib, a male patient, firmly rejects electroconvulsive therapy, or karant (shock) as it is known in Kashmir. Is this 
because his understanding was clouded by superstition and myths, as the psychiatrists claimed? Or could it be that in Kashmir, karant is associated also with electric shock, a technique of torture, frequently used in Kashmir during interrogation?

Packed with many narratives and experiences, Varma's book is deeply disturbing and incisive. It turns many assumptions, inferences and even the concept of care as a redemptive practice, on its head or inside out. It needs to be debated and discussed far more thoroughly for its content, rather than just its genealogy.

"Note: Cordon and search operations or crackdowns, as they came to be known locally, began in the 1990s when counter insurgency operations became population centric. The search for militants who might be hiding in people's homes would be conducted with an area being cordoned off. The men would be ordered to gather outside for interrogation and the women would, often, be alone whilst security forces searched the homes. There have been many complaints to human right bodies about torture, enforced disappearances, ransacking of homes and sexual violence that was allegedly perpetrated during these searches.

\section{References}

1. @Settled_Scholarship "This thread raises important ethical and political concerns about the ethnographic research and writing of US based anthropologist Saiba Varma....."Twitter. 2021 Sep 14, 11.27 pm [cited 2021 Dec 8]. Available from: twitter.com/settler_scholar/ status/1437837980618706952

2. Bhardwaj A. Book on Kashmir puts author's father, an ex-RAW official, in spotlight. Print. 2021 Sep [cited 2021 Dec 12]. Available from:https://theprint.in/india/book-on-kashmir-puts-authorsfather-an-ex-raw-official-in-spotlight/735700/

3. The Wire Staff. Does nondisclosure of familial proximity to 'security state' compromise research on Kashmir? Wire. 2021 Oct 3[cited 2021 Dec 8]. Available from: https://thewire.in/books/debate-doesfamilial-proximity-to-the-security-state-compromise-academicresearch-on-kashmir

4. Varma S. Personal communication to the author in email dated Nov 9, 2021. Cited with permission.

5. Ruddock A. Special Treatment. Student doctors at the All India Institute of Medical Sciences. Stanford: Stanford University Press; 2021. 296 pages.

6. PTI. J\&K: More civilians, security forces injured in 2016 than in 2010 . Economic Times. 2018 Jul 13[cited 2021 Dec 8]. Available from: https://economictimes.indiatimes.com/news/defence/jk-morecivilians-security-forces-injured-in-2016-than-in-2010/articleshow/ 59651760.cms?from $=\mathrm{mdr}$ 